\title{
Small Town Central City Revitalization: An Assessment Of Need And Criteria
}

\author{
Jeffrey P. Richetto*
}

For the past two decades, a good deal of research within the social sciences has been devoted to problems of urban-regional development and resettlement (Duncan, 1960; Berry, 1964; Siebert, 1969; Isard, 1975; Prescott and Lewis, 1975; Solomon, 1980). The substantial growth in indicators of national wealth and real income have been realized only within the context of considerable variation among regions throughout the United States. The post-World War II focus on the growth and cyclical effects of national urban economic policy has been complemented more recently by the realization that the spatial distribution of economic activity is an equally legitimate concern of policymakers at the local, state, and regional governmental levels. Although at a rudimentary stage the broad contours of a national and regional urbanization policy are developing, it is apparent that the specifics of such policies must be based on the principal socio-economic problems engendered along the size continuum of urbanregional centers. It is within this context that this study examines the relationships between large metropolitan centers and surrounding smaller towns, particularly those links that bear on the phenomenon of small town central city revitalization. ${ }^{1}$ By focusing on the United States' experience, the purpose of this paper is twofold: (1) to demonstrate the need for small town revitalization, and (2) to identify those elements important for designing a workable small town revitalization program.

\section{THE NEED FOR SMALL TOWN REVITALIZATION}

Central city revitalization has been a planning philosophy adopted by an increasing number of both large and small cities. Although past revitalization efforts have focused on larger metropolitan centers where need for such rejuvenation has been most demonstrated (Redstone, 1976; Libassi and Hausner, 1977; Todd, 1979; Sanders, 1980), migration patterns have been changing; traditional rural-to-urban movements have given way to more contemporary urban-to-rural and suburban-to-exurban movements. These population shifts have been accompanied by a variety of private sector responses. In particular, retail activities wishing to serve these populations have responded; regional shopping centers are springing up near and in the outlying countryside. In addition, the construction 
of regional transportation networks has substantially increased the accessibility of suburban retail and office nucleations to outlying smaller communities. Consequently, a growing number of these smaller communities, specifically their central business district, face the common problem of maintaining their economic base. Unfortunately, those elements which have contributed and continue to contribute to the economic stability and growth in downtown areas of larger cities are neither necessarily transferable nor appropriate for the economic restoration of downtown areas in smaller urban centers.

The emergence and criticality of small town revitalization may be largely explained by four factors: ${ }^{2}(1)$ population movement, (2) locational preference of economic activity, (3) mobility, and (4) energy. Although each factor has helped to transform the socio-spatial and economic landscape of the American metropolitan center, it has been the combination of these factors which has resulted in a growing number of smaller-sized, surrounding urban centers to face the problem of economic survival.

Historically, the population base of virtually all metropolitan areas experienced growth. However, over the last three decades it has become commonplace for the population of metropolitan centers, particularly the central city, to decline. Population statistics of central cities and their surrounding rings are summarized for fifteen major U.S. urban centers in Table 1. In short, the last three decades have witnessed a remarkable shift away from traditional rural-to-urban migration movement (prevalent since the Industrial Revolution) to an intraurban flow emphasizing a central city-to-suburb pattern. Berry and Dahmann (1977) note that when all three components of population change-natural increase, international, and interregional migration-are considered, central cities experienced an absolute population loss of nearly two million people ( 3.2 percent of their total population) from 1970 to 1975 . In the succeeding two-year period more than one million people moved from central cities than moved into them. During this same period, suburban rings experienced a twelve percent increase in total population.

More recently, however, suburbanization has spawned a back-to-thecountryside movement, i.e., a suburban-to-exurban pattern, Table 2. This outward, as opposed to inward, movement of households has been closely tied to the accumulation of affluence and mobility. Namely, exurban development has largely reflected the needs and wants of incoming middle and upper income residents whose spatial mobility and effective demand in the market is greatest (Richetto, 1983). Numerous factors may be postulated for inferring the motivations of migrants and attractions of life in exurban areas and small towns throughout the 1970s. First, economic and employment opportunities have become increasingly decentralized by virtue of: (1) technological changes including manufacturing processes, communication systems, and transportation facilities, (2) the development of an integrated intra and interurban transportation network, and (3) public programs encouraging the location of 'growth' activities in nonmetropolitan areas. Second, the recently renewed search for energy has resulted in explosive small town growth in many exurban regions 
TABLE 1.

Total Population of Urbanized Areas and Decennial Growth Rates, $1950-1970 * *$

\begin{tabular}{|c|c|c|c|c|c|}
\hline \multirow[b]{2}{*}{ Urbanized Area } & \multicolumn{3}{|c|}{$\begin{array}{l}\text { Total Populations } \\
\text { (thousands) }\end{array}$} & \multicolumn{2}{|c|}{$\begin{array}{c}\text { Decennial Growth } \\
\text { Rates (\%) }\end{array}$} \\
\hline & 1950 & 1960 & 1970 & $1950-60$ & $1960-70$ \\
\hline \multicolumn{6}{|l|}{ New York:* } \\
\hline City $\ldots \ldots \ldots \ldots \ldots$ & 8,891 & 8,743 & 8,820 & -2 & +1 \\
\hline Ring $\ldots \ldots \ldots \ldots$ & 3,405 & 5,372 & 7,387 & +58 & +38 \\
\hline \multicolumn{6}{|l|}{ Los Angeles:* } \\
\hline City $\ldots \ldots \ldots \ldots \ldots$ & 2,221 & 2,823 & 3,175 & +27 & +12 \\
\hline Ring $\ldots \ldots \ldots \ldots \ldots$ & 2,147 & 3,666 & 5,177 & +70 & +41 \\
\hline \multicolumn{6}{|l|}{ Chicago:* } \\
\hline City $\ldots \ldots \ldots \ldots \ldots$ & 3,897 & 3,898 & 3,697 & 0 & -5 \\
\hline Ring $\ldots \ldots \ldots \ldots \ldots$ & 1,024 & 2,061 & 3,017 & +101 & +46 \\
\hline \multicolumn{6}{|l|}{ Philadelphia: } \\
\hline City ............... & 2,072 & 2,003 & 1,949 & -3 & -3 \\
\hline Ring $\ldots \ldots \ldots \ldots \ldots$ & 851 & 1,633 & 2,073 & +92 & +27 \\
\hline \multicolumn{6}{|l|}{ Detroit: } \\
\hline City ..... & 1,850 & 1,670 & 1,496 & -10 & -10 \\
\hline Ring $\ldots \ldots \ldots \ldots \ldots$ & 810 & 1,867 & 2,475 & +131 & +33 \\
\hline \multicolumn{6}{|l|}{ San Francisco:* } \\
\hline City $\ldots \ldots \ldots \ldots \ldots$ & 1,160 & 1,158 & 1,077 & 0 & -7 \\
\hline Ring $\ldots \ldots \ldots \ldots \ldots$ & 862 & 1,273 & 1,911 & +48 & +50 \\
\hline \multicolumn{6}{|l|}{ Boston: } \\
\hline City $\ldots \ldots \ldots \ldots \ldots \ldots$ & 801 & 697 & 641 & -13 & -8 \\
\hline Ring $\ldots \ldots \ldots \ldots \ldots$ & 1,432 & 1,716 & 2,015 & +20 & +17 \\
\hline \multicolumn{6}{|l|}{ Washington: } \\
\hline City $\ldots \ldots \ldots \ldots \ldots$ & 802 & 764 & 757 & -5 & -1 \\
\hline Ring $\ldots \ldots \ldots \ldots \ldots$ & 485 & 1,045 & 1,725 & +115 & +65 \\
\hline \multicolumn{6}{|l|}{ Cleveland: } \\
\hline City $\ldots \ldots \ldots \ldots \ldots$ & 915 & 876 & 751 & -4 & -14 \\
\hline Ring $\ldots \ldots \ldots \ldots \ldots$ & 469 & 909 & 1,209 & +94 & +33 \\
\hline \multicolumn{6}{|l|}{ Saint Louis: } \\
\hline City ...... & 857 & 750 & 622 & -12 & -17 \\
\hline Ring $\ldots \ldots \ldots \ldots \ldots$ & 543 & 918 & 1,261 & +69 & +37 \\
\hline \multicolumn{6}{|l|}{ Pittsburgh: } \\
\hline City $\ldots \ldots \ldots \ldots \ldots \ldots$ & 677 & 604 & 520 & -11 & -14 \\
\hline Ring $\ldots \ldots \ldots \ldots \ldots$ & 856 & 1,200 & 1,326 & +40 & +10 \\
\hline \multicolumn{6}{|l|}{ Minneapolis:* } \\
\hline City ............... & 833 & 796 & 744 & -4 & -7 \\
\hline Ring $\ldots \ldots \ldots \ldots \ldots$ & 283 & 581 & 960 & +105 & +65 \\
\hline
\end{tabular}


TABLE 1.

Total Population of Urbanized Areas and Decennial Growth Rates, 1950 - 1970**

\begin{tabular}{|c|c|c|c|c|c|}
\hline \multirow[b]{2}{*}{ Urbanized Area } & \multicolumn{3}{|c|}{$\begin{array}{l}\text { Total Populations } \\
\text { (thousands) }\end{array}$} & \multicolumn{2}{|c|}{$\begin{array}{c}\text { Decennial Growth } \\
\text { Rates }(\%) \\
\end{array}$} \\
\hline & 1950 & 1960 & 1970 & $1950-60$ & $1960-70$ \\
\hline $\begin{array}{l}\text { Houston: } \\
\quad \text { City } \ldots \ldots \ldots \ldots \ldots \ldots \ldots \\
\text { Ring } \ldots \ldots \ldots \ldots \ldots \ldots\end{array}$ & $\begin{array}{l}596 \\
104\end{array}$ & $\begin{array}{l}938 \\
202\end{array}$ & $\begin{array}{r}1,233 \\
445\end{array}$ & $\begin{array}{l}+57 \\
+93\end{array}$ & $\begin{array}{r}+31 \\
+120\end{array}$ \\
\hline $\begin{array}{l}\text { Baltimore: } \\
\quad \text { City } \ldots \ldots \ldots \ldots \ldots \ldots \\
\text { Ring } \ldots \ldots \ldots \ldots \ldots \ldots\end{array}$ & $\begin{array}{l}950 \\
212\end{array}$ & $\begin{array}{l}939 \\
480\end{array}$ & $\begin{array}{l}906 \\
674\end{array}$ & $\begin{array}{r}-1 \\
+126\end{array}$ & $\begin{array}{r}-4 \\
+40\end{array}$ \\
\hline $\begin{array}{l}\text { Dallas: } \\
\quad \text { City } \ldots \ldots \ldots \ldots \ldots \ldots \ldots \\
\text { Ring } \ldots \ldots \ldots \ldots \ldots \ldots\end{array}$ & $\begin{array}{l}434 \\
105\end{array}$ & $\begin{array}{l}680 \\
253\end{array}$ & $\begin{array}{l}844 \\
494\end{array}$ & $\begin{array}{r}+56 \\
+141\end{array}$ & $\begin{array}{l}+24 \\
+96\end{array}$ \\
\hline $\begin{array}{l}\text { Average: } \\
\quad \text { City } \ldots \ldots \ldots \ldots \ldots \ldots \ldots \\
\text { Ring } \ldots \ldots \ldots \ldots \ldots\end{array}$ & $\begin{array}{r}1,797 \\
906\end{array}$ & $\begin{array}{l}1,823 \\
1,545\end{array}$ & $\begin{array}{l}1,815 \\
2,143\end{array}$ & $\begin{array}{r}+1 \\
+71\end{array}$ & $\begin{array}{r}0 \\
+39\end{array}$ \\
\hline
\end{tabular}

* More than one central city in these urbanized areas.

**SOURCE: U.S. Bureau of the Census, Census of Population: 1950, vol. 2, Table 33; Census of Population: 1960, Vol. 1, Table 20; Census of Population: 1970, Vol. 1, Table 24 (Washington, D.C.: Government Printing Office, various).

throughout the United States. For example, a resurgence of coal mining in Appalachia has helped change the state of West Virginia from net outmigration (for many decades) to net in-migration. Furthermore, the search for alternative energy sources has diminished the concern of fuel shortages and, therefore, the need to reside closer in to places of employment, shopping, and recreation. A third and final factor accounting for nonmetropolitan population growth during the 1970s reflects not only the preferences by urbanites for small town and rural living but also their increased ability to act on such preferences (Beale, 1975; DeJong, 1977; De Jong and Sell, 1977). Overall, the three explanatory factors suggest a heterogeneous group of migrants consisting of retirees, financially established middle-aged households, and succeeding young wage earners. As a result, private and public sector activities including industry, retail, housing, and transportation have responded as well as reinforced the development of this suburban-exurban exodus.

The growth and decentralization of the metropolitan population has been equally matched by significant changes in the economic structure of central cities and suburban rings. The dispersion of retail and industrial establishments, along with the creation of a suburban and exurban housing industry, closely followed the centrifugal drift of the metropolitan population, Tables 3 and 4 . According to the International Council of Shopping Centers (1974), more than fourteen thousand shopping centers have been constructed in the United States since 1954 primarily to serve 
TABLE 2.

Migration Between Metropolitan and Nonmetropolitan Areas:

1965-1970, 1970-1975 and 1975-1980.*

\begin{tabular}{lrrr}
\hline & $1965-70$ & $1970-75$ & $1975-80$ \\
$\begin{array}{lrrr}\text { Metropolitan to Non- } \\
\text { metropolitan Migrants }\end{array}$ & $5,457,282$ & $6,721,000$ & $9,736,201$ \\
$\begin{array}{l}\text { Nonmetropolitan to } \\
\text { Metropolitan Migrants }\end{array}$ & $5,809,415$ & $5,127,000$ & $6,357,210$ \\
$\begin{array}{l}\text { Gross Migrants } \\
\text { Net Migrants to }\end{array}$ & $11,266,697$ & $11,848,000$ & $16,093,411$ \\
$\begin{array}{l}\text { Metropolitan Areas } \\
\text { Initial Metropolitan }\end{array}$ & 352,133 & $-1,594,000$ & $-3,378,991$ \\
$\begin{array}{l}\text { Population Base } \\
\text { Initial Nonmetropolitan }\end{array}$ & $117,825,098$ & $122,449,000$ & $133,689,135$ \\
$\begin{array}{l}\text { Population Base } \\
\text { Gross Migration Rate }\end{array}$ & $55,832,216$ & $57,041,000$ & $73,692,853$ \\
Metropolitan Out-Migration Rate $^{\mathrm{b}}$ & 64.9 & 66.0 & 77.6 \\
Nonmetropolitan Out-Migration $^{\text {Rate }}{ }^{\mathrm{b}}$ & 46.3 & 54.9 & 72.8 \\
\hline
\end{tabular}

${ }^{a}$ Ratio of total migrants to total initial population times 1000 .

${ }^{\mathrm{b}}$ Ratio of out-migrants to initial population times 1000.

*SOURCES: U.S. Bureau of the Census, Current Population Reports, Series P-20, Mobility of the Population of the United States: March 1970 to March 1975, No. 285 (1975a); Geographical Mobility: March 1975 to March 1980, No. 331 (1980).

expanding suburban populations. During the same period, the central cities of the nation's twenty-three largest SMSAs suffered an average loss of seventeen thousand manufacturing positions while their suburban counterparts enjoyed an average gain of nearly eighty-five thousand positions. Similarly, new housing construction has favored suburban and, more recently, exurban locations. This is particularly true in the United States where demand for homeownership is closely linked with demand for single-family, detached housing (James, 1976). As a result, a greater proportion of new housing production has occurred and is likely to continue to occur in the suburbs and beyond. ${ }^{3}$

A third factor which has contributed to the need for small town revitalization is transportation. Historically, transportation expenditures in the United States have focused on the development of a highly integrated intra and inter-urban freeway system. The catalyst for this focus was the 1956 Interstate Highway Act through which federal funds accounted for ninety percent of local construction costs. As a result, suburbs are now interlaced by their own system of circumferential and radial freeways which have created locations of great accessibility for serving the central 
TABLE 3.

Employment Changes by Major Sector, 1967-1972.*

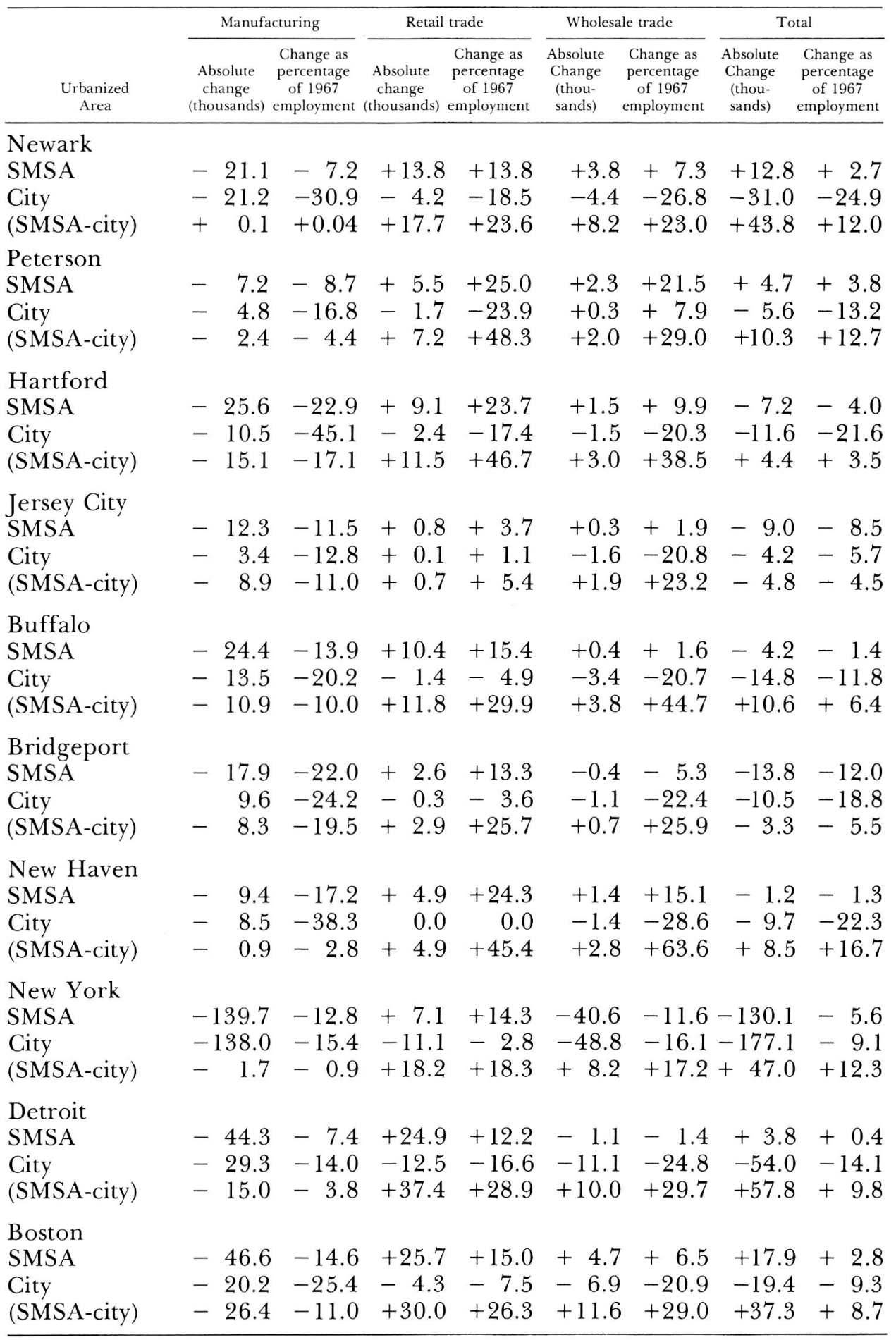


TABLE 3.

Employment Changes by Major Sector, 1967-1972.*

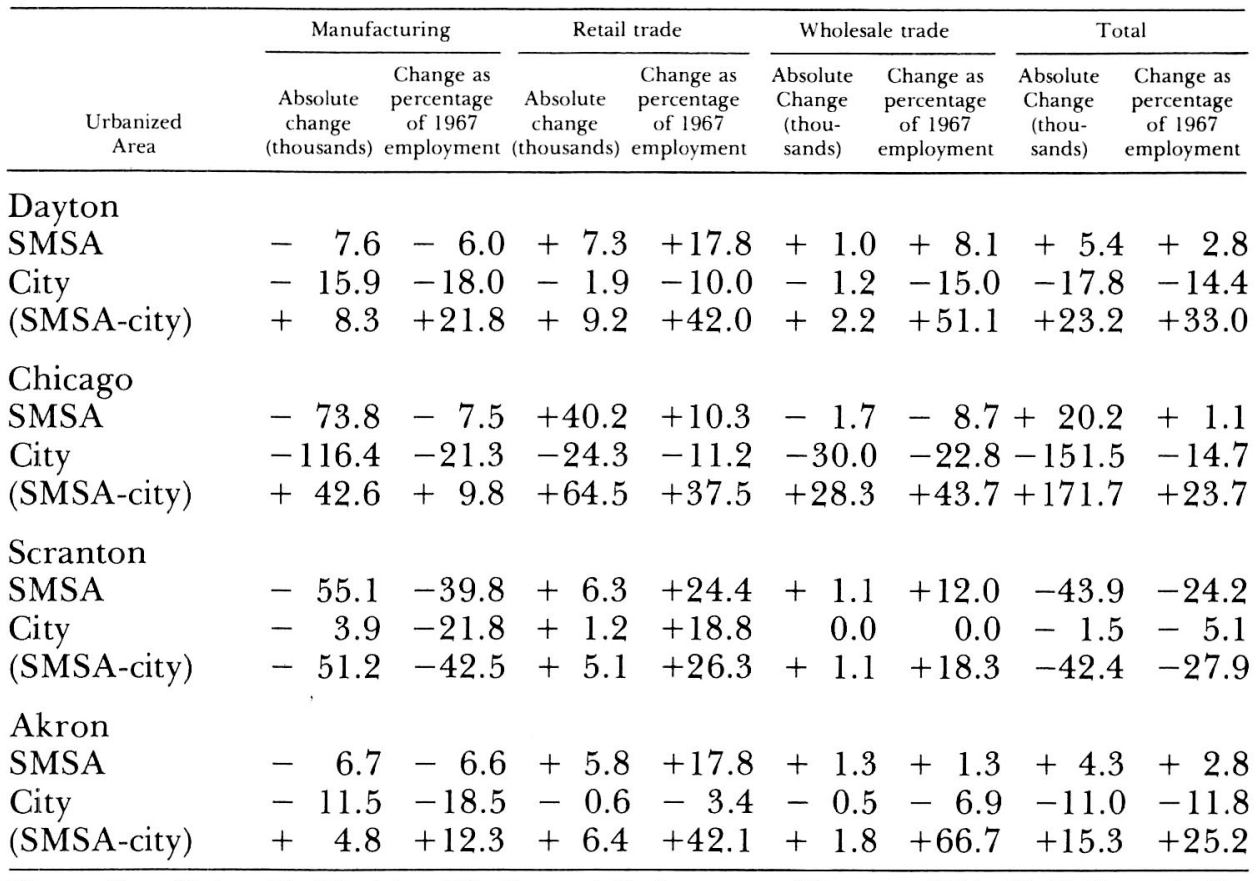

*Source: Garn, H. A. and L. C. Ledebur, "The Economic Performance and Prospects of Cities," in The Prospective City, A. P. Solomon, ed. The MIT Press: Cambridge, 1980.

city, the suburban ring, and the exurban area. As a consequence, suburbs have become the locations of new manufacturing activity as well as extensive regional retail and business centers capable of supplying employment, product, and service needs for those households within and beyond the metropolitan boundary.

A fourth and final factor underlying the need for small town revitalization centers on energy. In retrospect, the processes of suburbanization and exurbanization have been fueled by the availability of inexpensive energy. The result has been a pattern of urban development which, at the macrolevel, is spatially concentrated and oriented toward energy-intensive production. Within these concentrations, however, there have been great energy-consuming efforts to achieve the amenities of deconcentrationsolitude, space, and privacy. Place of employment and residence, the wealthy and the less fortunate, the pristine and the polluted are effectively separated in urban areas. This separation has been maintained by virtue of low-cost mobility and through implicit and explicit policies (Burton, 1979). Furthermore, the development of the synthetic fuels industry is viewed by many as a future insurance against severe cutbacks in mobility (Camby, 1981). As a result, a description of the typical urban-exurban relationship throughout the 1980s will likely reflect current residential preferences, a 
continued buildup of the outer city, and if unchecked, an ever-worsening economic situation for smaller communities.

\section{DESIGNING A SMALL TOWN REVITALIZATION PROGRAM}

As stated earlier, central city revitalization has become increasingly necessary for both large and small urban centers in restoring their ability to effectively compete in the open market. Emphasis, however, has been placed on the development and implementation of these programs for larger metropolitan centers. As a consequence, the focus of revitalization efforts has been to create a downtown environment conducive to day/night activity. Activities included in these programs are: (1) the extension of facilities to attract community residents into the central business district after business hours, (2) the diversification and increase in employment opportunities, (3) the provision of housing units to serve a mixture of income levels, (4) the construction of multilevel parking structures and protected pedestrian walkways, and (5) the construction of a balanced mix of new office, retail, and recreational facilities.

Unfortunately, while these activities have contributed and continue to contribute to the potential success of larger city revitalization programs, they often overstate the land use, financial, and market capabilities of smaller communities. For example, the set of activities assumes that a downtown area has an adequate supply of land parcels which are either presently undeveloped or 'ripe' for redevelopment. Furthermore, the implementation of these activities is based upon the virtually unlimited access to private and public funds. Petersen (1976) reports that smaller urban communities are disadvantaged in the municipal bond market largely as a function of their size. Consequently, these communities must turn within and rely heavily upon limited local sources of credit and private contributions. Finally, the level of economic success achievable through the aforementioned activities depends upon both a large population base, a significant proportion of which is willing to patronize the downtown area, and the degree of community input utilized for evaluating activity decisions.

Together, these three considerations-land use, financial, and market—-distinguish large from small city resources and capabilities as well

\section{TABLE 4.}

Average Employment (Gain or Loss) in Central Cities and Suburbs by Major Employment Sector, 1967-1972 (average percent change)*

\begin{tabular}{lcccr}
\hline & $\begin{array}{c}\text { Manufac- } \\
\text { turing }\end{array}$ & $\begin{array}{c}\text { Retail } \\
\text { trade }\end{array}$ & $\begin{array}{c}\text { Wholesale } \\
\text { trade }\end{array}$ & Total \\
Central cities & -22.2 & -7.2 & -17.5 & -13.6 \\
Suburbs & -5.6 & +33.0 & +37.5 & +8.2 \\
\hline
\end{tabular}

*Source: Garn, H. A. and L. C. Ledebur, "The Economic Performance and Prospects of Cities," in The Prospective City, A. P. Solomon, ed. The MIT Press: Cambridge, 1980. 
as provide a basis from which to design a revitalization program tailored to small town needs. The remainder of this paper will develop more fully the market consideration.

\section{THE NATURE AND ROLE OF THE MARKET IN SMALL TOWN REVITALIZATION PROGRAMS}

The articulation of redevelopment plans in metropolitan centers largely reflects the interests of the local mercantile and community leaders. In the smaller town context, however, this approach could be quite misleading and less desirable. The simple fact is downtown areas of metropolitan centers, as opposed to small towns, draw from a substantially greater population base which is characteristically more heterogeneous. In other words, the economic viability of small town CBDs is dependent upon patronization by the community as a whole rather than a select portion of its residents. Consequently, the formulation of smaller town revitalization efforts must depart from conventional wisdom and, instead, focus on blending together the interests of the local merchants, community leaders, and the community population as a whole.

Appropriate questions to be addressed include: (1) is the shopping environment important for maintaining and attracting in new customers; if so, to what extent and what elements constitute an attractive shopping environment, (2) do cost and availability of parking affect the potential success of a small town revitalization program, and (3) are cost and selection of merchandise pertinent for restoring the economic viability of small town CBDs? Answers to these and other questions are critical for assessing properly those elements resulting in a workable and successful redevelopment strategy. It is within this context that a detailed survey study was developed and implemented for two small towns in the state of Illinois. ${ }^{4}$

\section{THE CASE STUDY}

The purpose of the survey study is threefold: (1) to identify and investigate variations in interests and attitudes between the local merchants and the community-at-large, (2) to assess existing and potential shopping behavior patterns of community merchants and residents, and (3) to estimate the extent to which changes in current downtown conditions (relative to alternative shopping areas) would lead to an improved business outlook. The telephone survey study consisted of 539 residents ( $2 \%$ of the population) and 62 merchants (42\% of the population). Respondents were selected randomly based on the last four digits completing the telephone number whereas the three-digit telephone prefix determined the proportion of total respondents to be sampled from any one given area. Individuals were questioned on criteria ranging from shopping routines to merchandising considerations, from suggested structural downtown renovations to rank-ordering identified renovations, Figures 1-3. Furthermore, data on a select number of demographic attributes were collected in an effort to identify factors underlying an individual's need (age), interest (length of residency), and response (level of mobility) to 

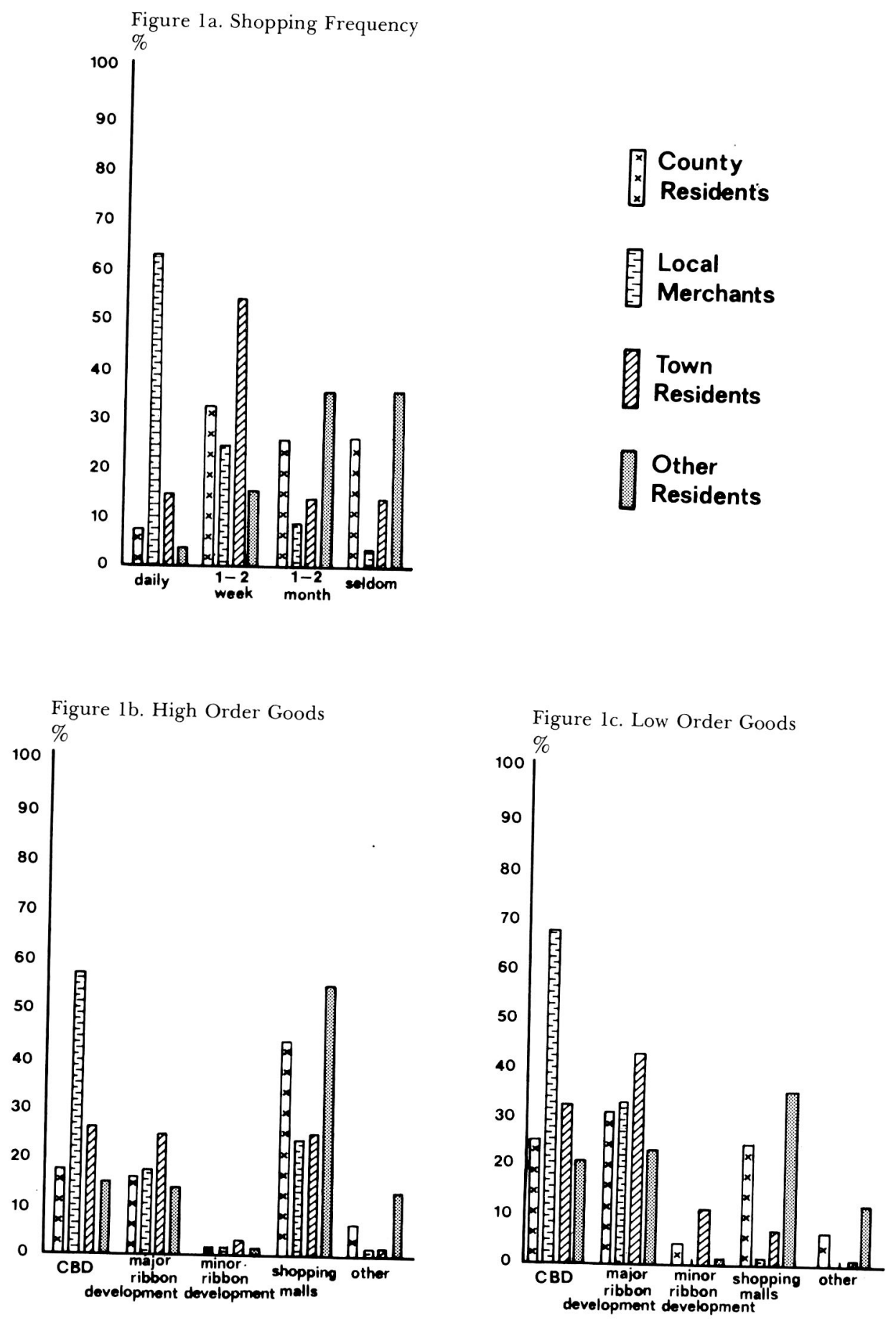

Figure 1. Frequency of Shopping by Place and Type of Goods. 
a revitalization program, Figure 4 . Finally, the respondents were partitioned into four categories to examine whether or not distance influences shopping destination; if so, to what extent and to contrast and compare community and local merchant viewpoints. In order to accomplish this task contingency table analysis was employed. Cross-tabulation tables were constructed, chi-square and lambda values were calculated to test statistical significance and measure level of association between variables respectively, ${ }^{5}$ and a number of inferences were drawn from the statistical results.

For example, the frequency of consumer shopping activity is a measure of a retail district's economic performance and its relative position in the hierarchy of competing shopping areas. The set of diagrams in Figure 1 illustrates this measure for both small towns sampled. As expected, local merchants load high on the daily category $(62.9 \%)$ because the central business district is their place of work, Figure la. Furthermore, as frequency of shopping activity declines, there is a corresponding decline in the number of local merchants included in these less frequent categories. A similar pattern is observed for city residents; however, the peak value occurs in the once-twice per week category. In comparison, households living outside the county and, to a lesser extent, living outside the city limits load ever higher on the less frequent categories.

One plausible and intuitively appealing explanation for this variation in frequency of CBD shopping is distance. The pattern observed for all four consumer groups conforms to a classic distance decay relationship; as distance increases from the CBD, frequency of CBD shopping decreases. However, given that a significant proportion of exurban households have access to personal transportation ${ }^{6}$ and that they are accustomed to longdistance travelling for normal day-to-day activities, the role of distance may be of secondary importance. Perhaps a more fundamental consideration for explaining small town shopping patterns is consumer demand for goods and services.

In an effort to measure demand (or frequency of purchase) for various goods and services Berry and Garrison (1958) distinguish high from low order goods and services. ${ }^{7}$ They conclude that the demand for higher order goods is less than for lower order goods by virtue of higher price, greater durability, infrequent usage, and function. As a result, the frequency of purchase of higher order goods will be less than that of lower order goods. Translating this relationship into distance, households should be willing to travel further to purchase higher order goods because they purchase these longer lasting, higher priced items less frequently. Figure $1 \mathrm{~b}$ illustrates that for all consumer groups (with the exception of the local merchants) higher order goods are largely purchased in outlying retail nucleations as opposed to the closer-in central business district. However, nearly one-half of the local merchants patronize non-CBD establishments for higher order goods.

The purchase of lower order goods reveals a somewhat similar pattern, Figure 1c. Again, excepting the local merchants, a greater proportion of all consumer groups purchase these goods from outlying establishments 

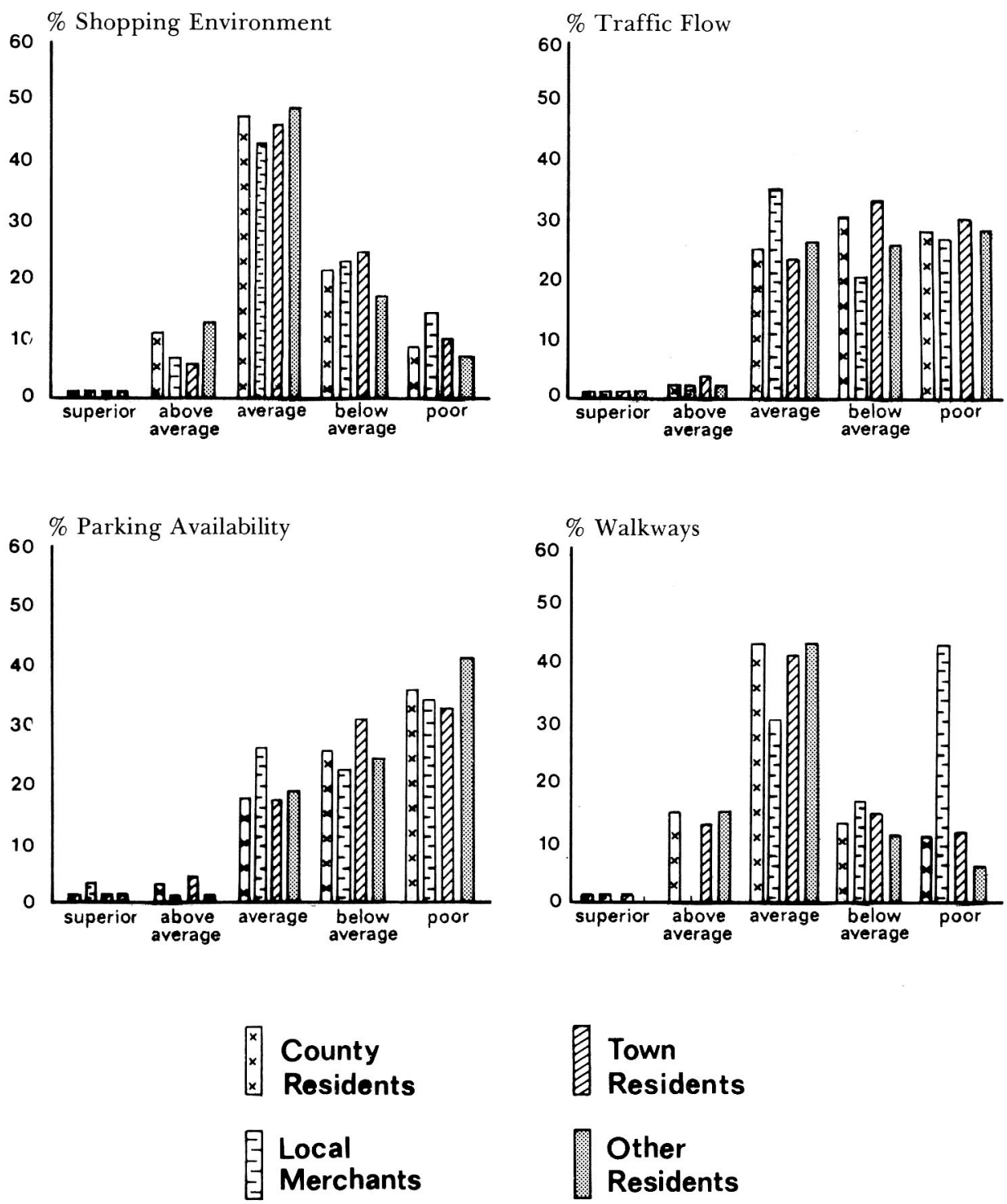

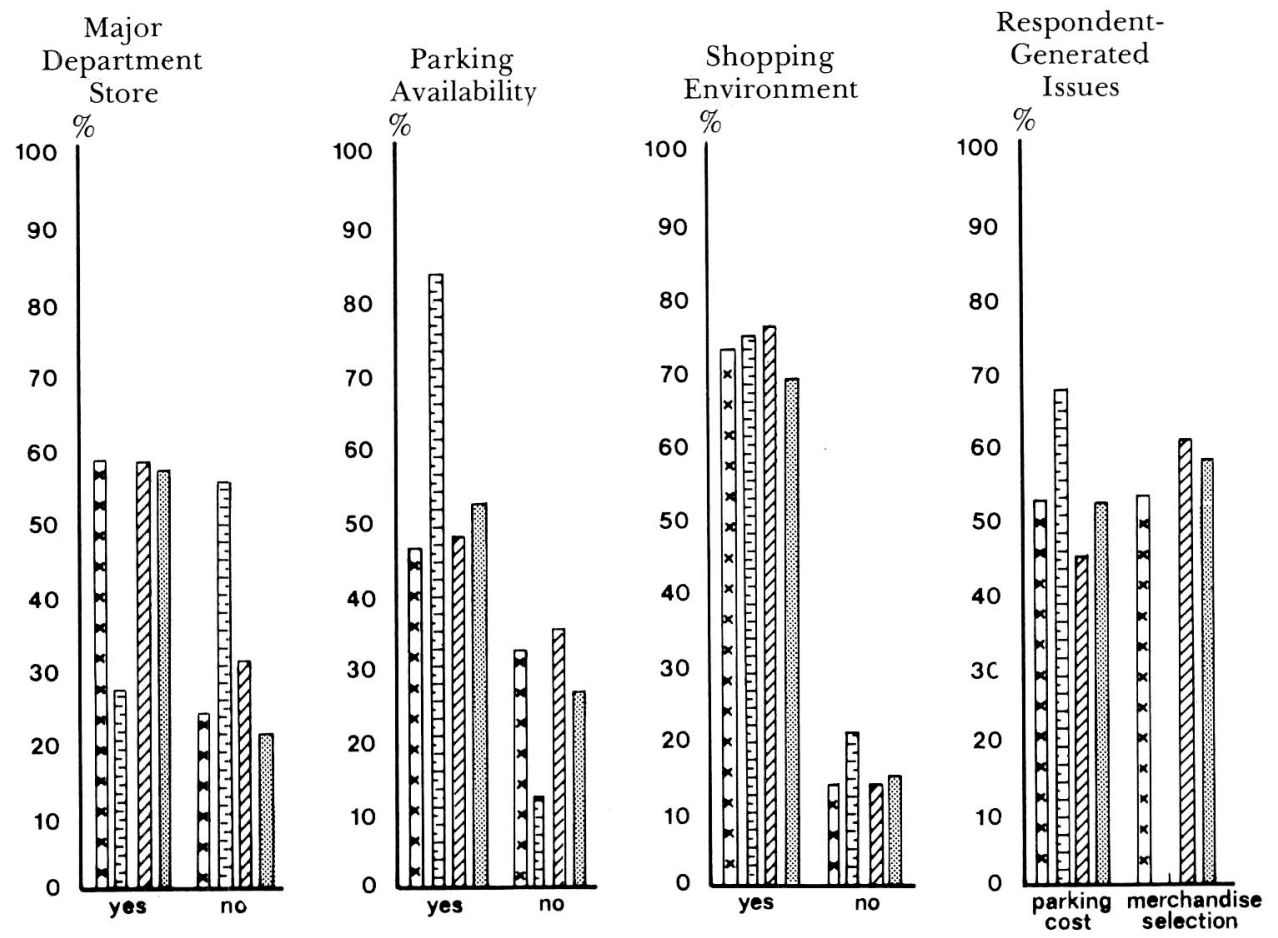
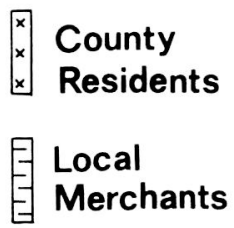

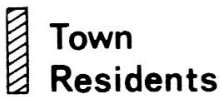

\section{Other \\ Residents}

Figure 3. A Comparison of Local Merchant and Community Interests.

rather than the $\mathrm{CBD}$. This latter shopping pattern, in particular, suggests the likelihood that factors aside from distance and consumer demand influence shopping destination. Swanson, et al. (1979), indicate that there are at least four other factors that influence a smaller town household's selection of one shopping area over another. These factors include: shopping environment, traffic flow, parking availability, and conditions of pedestrian walkways.

Figure 2 summarizes both household and local merchant responses for these four considerations. Together, these diagrams reveal a consistent pattern not only between consumer groups but also among the four factors. Namely, the central business district of both small towns surveyed were viewed from average to poor on all four criteria. Importantly, this view point has become characteristic of small towns in general. As a consequence, alternative shopping districts (e.g., regional shopping malls) have become focal points for the small town customer. In short, there is a 

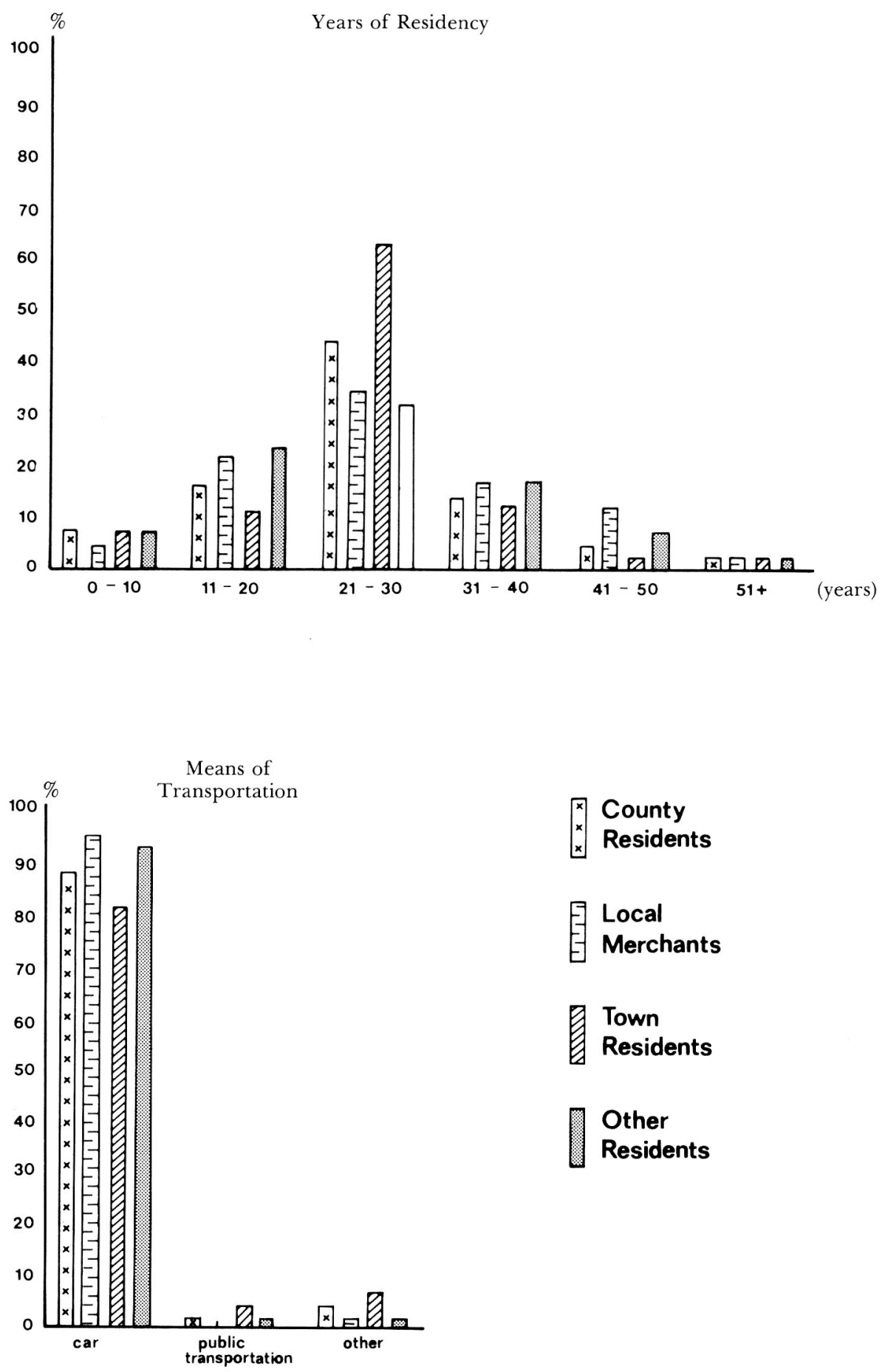

$\left[\begin{array}{ll}x \\ \times & \text { County } \\ x & \text { Residents }\end{array}\right.$
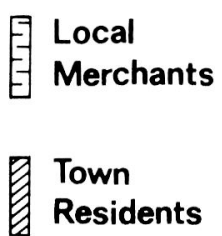

Other

Residents

Figure 4. Selected Attributes Influencing Commitment to one's Community. 
demonstrated need for improvement in CBD conditions. In determining specific areas for improvement, however, a careful analysis of local merchant and community interests is required. On the one hand, local merchants in smaller towns often share in the financial support of a revitalization program and, therefore, are more likely to act upon their interests (Bryce, 1976). On the other hand, the community-at-large will more likely patronize a redeveloped CBD if their interests are fulfilled (Goetze, 1981). This situation, typical for many smaller as well as larger urban centers, has resulted in a significant number of restored yet dying central business districts (Nix, 1976; Gluck and Meister, 1979).

Figure 3 illustrates the major differences between local merchant interests and those expressed by the community. The three areas of greatest disagreement involve whether or not a major department store should be located in the CBD, the availability of parking, and the variety and quality of merchandise. The only area of agreement is the mutual concern for upgrading the shopping environment of the CBD.

As expected, these sharp differences in perceived need lead to corresponding differences in prioritizing these needs. Based upon the principle of a limited budget, local merchants list those problem areas to be addressed by a revitalization program in the following order: (1) parking availability, (2) parking cost, and (3) shopping environment. In comparison, the ordering of problem areas by the community is: (1) shopping environment, (2) variety and quality of merchandise, (3) major department store, and (4) parking space and cost.

\section{SUMMARY}

In summary, this study demonstrates the need to develop small town CBD revitalization programs. These semi-urban, semi-rural centers have been increasingly subject to intense peripheral growth and development by neighboring larger metropolitan centers. A well developed regional transport network, along with a high degree of personal mobility, has provided residents in outlying smaller communities easy access to a number of alternative shopping areas located on the fringe of the metropolis. Other on-going issues and processes supportive of small town revitalization include a strong suburban and exurban migration component, an accompanying shift in location preference by numerous economic activities to serve this newly formed financially established market, and the development of an extensive liquid energy program ensuring continued high levels of personal mobility.

The study also attempts to distinguish larger city from smaller town revitalization efforts. Of significance are the three categories of land use, financial resources, and market structure. Focusing on the last category, the findings suggest that the potential success of small town revitalization programs depends heavily on the participation by the community as a whole, not only as consumers of offered products and services by downtown activities but also for input relating to the development of revitalization programs encouraging downtown patronization. It is hoped that this study 


\section{provides a first step for developing effective revitalization programs for smaller-sized urban centers throughout the United States.}

\section{FOOTNOTES}

${ }^{1}$ Small towns are defined to be any incorporated or unincorporated area with a population size ranging from 5,000 to 35,000 inhabitants (Swanson, et al., 1979).

${ }^{2}$ The conceptualization of these four factors as they relate to the need for small town revitalization is embodied in central place theory and diffusion analysis.

${ }^{3}$ In 1970 , for example, almost 40 percent of new housing units in metropolitan areas were built in central cities; by 1976 this figure had dropped below 30 percent (U.S. Bureau of the Census, 1977).

${ }^{4}$ The towns of DeKalb, Illinois (28,500 population) and Sycamore, Illinois (11,000 population) constituted the survey study.

${ }^{5}$ Overall, the chi-square and lambda values indicate a strong statistical relationship between variables and respondent categories, Figures 1-4.

${ }^{6}$ Over ninety percent of the respondents surveyed owned at least one automobile.

${ }^{7}$ High order goods and services include: major appliances, automotive, electronic equipment, furniture, and real estate, among others. Low order goods and services include: housewares, food, financial, and bakery, among others.

\section{REFERENCES}

Beale, C. L. The Revival of Population Growth in Nonmetropolitan America. Washington, D.C.: U.S. Department of Agriculture, Economic Research Service, 1975.

Berry, B. "Cities as Systems Within Cities," Papers of Regional Science Association, 13:147-163 (1964).

Berry, G., and Garrison, W. "The Functional Bases of the Central Place Hierarchy," Economic Geography, 34: 35-49. (1958).

Berry, B., and Dahman, D. Population Redistribution in the United States in the 1970's. Washington, D.C.: National Academy of Sciences, 1977.

Bryce, H. Small Cities in Transition: The Dynamics of Growth and Decline. 1976.

Burton, D. J. "Energy and Urban Form." The Changing Structure of the City, G. A. Tobin, ed. 1979.

Camby, T. V. "Synfuels Fill 'er Up!," National Geographic, 74-94 1981.

DeJong, G. F. "Residential Preferences and Migration," Demography 14:169-178 (1977).

DeJong, G. F., and Sell, R. R. "Population Redistribution, Migration and Residential Preferences," Annals of the American Academy of Political and Social Sciences 429:130-144 (1977).

Duncan, O. D. Metropolis and Region.:, 1960.

Gluck, P., and Meister, R. J. Cities in Transition.: 1979.

Goetze, R. "Citizen Expectations Can Determine the Success of Local Revitalization Programs," Journal of Housing, 1:205-212 (1980.

Isard, W. Introduction to Regional Science.: 1975.

James, F. J. "Income Taxes, Homeownership and Urban
Land Use," paper presented at a joint session of the AEA and UEA (1976).

Libassi, P., and Hausner, V. Revitalizing Central City Investment.:, 1977.

Nix, H. L., Brooks, G. S., and Courtenay, B. C. "Comparative Needs of Large and Small Communities," Journal of Community Development and Society, 7:2 (1976).

Petersen, "The Borrowing Costs of Small City Borrowers," Small Cities in Transition: The Dynamics of Growth and Decline. Bryce (ed.). Chapter 7,: (1976).

Prescott, J., and Lewis, W., Urban-Regional Economic Growth and Policy.: 1975.

Redstone, L. G. The New Downtowns.: 1976.

Richetto, J. P. "The Breakdown in Rural Communities-Can We Stop It?" Long Range Planning, forthcoming (Feb. 1983).

Sanders, H. T. "Urban Renewal and the Revitalized City: A Reconsideration of Recent History.":, Urban Revitalization, D. Rosenthal, ed., 1980.

Siebert, H. Regional Economic Growth: Theory and Policy.:, 1969.

Solomon, A. P. The Prospective City.: 1980.

Swanson, B., Cohen, R., and Swanson, E. Small Towns and Small Towners: A Framework for Survival and Growth.: 1979.

Todd, D. "On Urban Spillovers and Rural Transformation," Regional Studies, 13:305-322 (3, 1979).

U.S. Bureau of the Census "Housing Authorized by Building Permits and Public Contracts," Construction Reports, C40, 1977. 